\title{
口腔常在細菌の増殖性と酸化還元酵素について
}

II. 口腔常在細菌が保有する酸化還元酵素について

\author{
菊池裕子 \\ 北海道大学歯学部口腔細菌学講座（指導 : 鈴木武教授)
}

〔受付 : 昭和 62 年 3 月 10 日]

\section{Studies on the growth of oral indigenous bacteria and their oxidoreductase activities \\ II. Oxidoreductase activities}

\author{
Hiroko E. Kikuchi \\ Department of Oral Microbiology, School of Dentistry, Hokkaido University \\ Nishi 7 chome, Kita 13 jo, Kita-ku, Sapporo, Hokkaido, 060 \\ (Chief: Prof. Takeshi Suzuki) \\ [Accepted for publication: March 10, 1987]
}

Key words : Oxidoreductase / oral / indigenous / bacteria / biological-protection

\begin{abstract}
In a preceding study, an index was given for bacteria with intermediate tolerances for oxygen which could express their aerobic to anaerobic potentials in a quantitative manner.

The purpose of this paper is to examine to what extent changes in that index might relate with the oxidoreductase activities in those oral indigenous bacteria under different oxygen conditions. The oxidoreductases studied in bacteria grown under aerobic and anaerobic conditions include NADH peroxidase, peroxidase, superoxide dismutase (SOD), and catalase. Isozyme of SOD was also studied in some bacteria using disc polyacrylamide electrophresis.

It is suggested that NADH peroxidase and superoxide dismutase (SOD) play a dominative role in the grown of oral indigenous bacteria under several oxygen concentrations.
\end{abstract}

\section{緒言}

口腔微生物叢, 特にプラーク中の 微生物叢の形 成および成熟には, 微生物間の共生, 拮抗,およ び宿主の 抵抗力，栄養の摂取などが関係する ${ }^{1,2)}$ 。 それらの因子のうちでも, 特に酸素の供給が微生 物叢の形成に 第 1 義的な影響を与えるものと考え られる。

前報においては，口腔常在細菌の増殖に及ぼす 酸素の影響を定量化する方法を考案し，得られた 指標が 各群において明らかに異なることを報告し

札幌市北区北13条西 7 丁目（广 060）
た ${ }^{3)}$ 。

本報では, 培養中の 細菌について, その増殖に 及ぼす酸素の影響と, 細菌自体が持つ酸化還元酵 素の質的，または量的な差との関連を検討した。 そのため, 異なる酸素条件下で培養した口腔常在 細菌の 保有する 各種の 酸化還元酵素の 分布, 活 性, およびアイソザイムの存在などについて測定 を行った。

材料と方法

1) 使用細菌

口腔常在細菌として, 以下の 細菌を実験に用 
いた。

すなわち, Neisseria mucosa S-11*4), N. subflava YN-1*4), Staphylococcus aureus $209 \mathrm{P}^{4)}$, Streptococcus salivarius S-6*4), Str. mitior S. $8^{* 4}$, Str. sanquis ATCC $10557^{51}$, Str. sanguis S-9*5), Str.sanguis NS-7*5), Str.mutans Ingbri$\mathrm{tt}^{6)}$, Str. mutans $1089^{* * 7)}$, Str. mutans MT

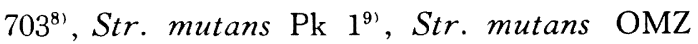
$175^{10)}$, Str. mutans B 13 ${ }^{11}$, Str. faecalis ATCC $19433^{12)}$, Str. faecalis A TCC $9756^{12)}$, Str. pyogenes IID 689 ${ }^{13,14}$, Lactobacillus acidophilus ATCC $4356^{151}$, Veillonella alcalescens ATCC $17748^{16)}$, Propionibacterium acnes ATCC $11827^{17)}$, Fusobacterium nucleatum IID $891^{18)}$ である。

対照菌種として Escherichia coli K 1219)，E. coli $\mathrm{K} 67^{19)}$, E. coli $\mathrm{B} / \mathrm{r}^{201}$, Proteus vulgaris IID $874^{21)}$, Salmonella enteritidis IID 60422), Micrococcus luteus NCTC 2665 $5^{23,24)}$, Pseudomonas aeruginosa S-2*4) 用いた。

2）培養法

実験には，嫌気性菌用培地である GAM ブイ ヨン培地（日水製薬，東京）を用いた。

細菌は, 一菌株について 好気振盪と静置の 2 条 件で, $37^{\circ} \mathrm{C} て ゙ 1 \sim 2$ 日間培養した。振盪培養は, 定温振盪機 (Gyrotory incubator shaker G24； New Brunswick Scientific Co., Inc., USA) を用いて $150 \mathrm{rpm}$ で行った。

3）洗滌菌体および 菌体破砕抽出液の調製

a）洗滌菌体の 調製

培養液を 遠心沈殿して $(8,000 \mathrm{~g}, 10$ 分間）菌体 を集め, この菌体を $0.05 \mathrm{M}$ リン酸緩衝液（ $\mathrm{pH}$ 7.0）を用いて 3 回遠心洗滌した後, 可及的に少量 の緩衝液中に 浮遊させた。この 濃厚菌液の 濃度 は，この一部を比濁すること，および乾燥菌量を 測定することにより求めた。

b）菌体破砕抽出液の調製

洗滌菌体を湿菌量 $0.5 \mathrm{~g} / \mathrm{ml}$ となるように 0.01 $\mathrm{M}$ リン酸緩衝液（pH 7.0）で調製し，これらを 菌体浮遊液とした。この 浮遊液中の細胞を, 超音

* 北海道大学歯学部口腔細菌学㩐坐分離株

** 爱知学院大学菌学部口腔微生物学請座分離株
波破砕機（Tomy UR-200; 富永，東京）を用い て $20 \mathrm{kHz}, 80 \mathrm{~W}$ で 3 分間作用させ破砕した。こ れを冷却遠心分離機（RC-5 ; Sorvall，USA）を 用いて $12,000 \mathrm{~g}, 60$ 分間遠心し，上清を得た。この 上清を上記緩衝液中で36時間透析し，菌体破砕抽 出液を調製した。

\section{4）酵素活性の検出と定量}

酵素活性は，培養期間 $1 \sim 2$ 日後の 定常期に測 定し, 最低 3 回の 測定の平均を取った。酵素活性 の検出には，点滴分析法および活性染色法を用 い，定量分析には 分光光度計 (Hitachi Model 200- 20 ；日立，東京）を用いて $25^{\circ} \mathrm{C}$ で測定した。

a）全 $\mathrm{NADH}$ 酸化活性の定量

全 $\mathrm{NADH}$ 酸化活性は, Dolin ${ }^{251}$ の方法に従い, $\mathrm{NADH}$ と過酸化水素を含む反応液中に菌体破砕 上清を加え， $\mathrm{NADH}$ の減少の割合を $340 \mathrm{~nm}$ の 吸光度の 減少より測定した。

Dolin はこの方法を部分精製標品の測定につい てのみ, 適用しているが, 本研究では, Uesugi と Yajima ${ }^{26)}$ に従い，本方法を菌体破砕抽出液の測定 について適用した。この場合，Lactobacillus では，全 $\mathrm{NADH}$ 酸化のうち，約 $7.5 \%$ oxidation によるものであり，残りが peroxidation に よることが Mizushima と Kitahara により報告 されている ${ }^{27)}$ 。従って，使用菌株によって oxidation と peroxidation の比率が異なる可能性はあ るが，全 $\mathrm{NADH}$ 酸化活性の簡便な定量法とし て十分適用可能であると思われる。

b) スーパーオキサイド・ディスムターゼ （SOD）活性の定量法

SOD 活性は Beauchamp および Fridovich の 方法 ${ }^{28)}$ に従い， xanthine-xanthine oxidase 系に よる nitroblue tetrazolium (NBT) の還元を SOD が阻害する現象を $560 \mathrm{~nm}$ の吸光度の減少 により 測定した。

c）SOD のアイソザイムの検出法

SOD のアイソザイムの検出は, Davis, および Ornstein の方法 ${ }^{291}$ に従ってディスク電気泳動を 実施した後, Beauchamp，および Fridovich の 方法 ${ }^{30}$ による 活性染色法に従って実施した。

d）カタラーゼ活性の定量法

カタラーゼ活性は, Beers と Sizer の方法 ${ }^{311}$ 
に従い，過酸化水素の消費率を $240 \mathrm{~nm}$ の吸光度 の減少から測定した。

カタラーゼ活性の 測定法に関し，過マンガン酸 カリウム $\left(\mathrm{K}_{2} \mathrm{MnO}_{4}\right)$ よる滴定法 ${ }^{31}$ と過酸化水素 の $240 \mathrm{~nm}$ 吸光度測定法 ${ }^{32 !}$ とを比較検討した。そ の 結果, 市販の精製カタラーゼでは, 両方法によ って同じ活性值が 得られたが，菌体破砕抽出液で は，過マンガン酸カリウム法による 滴定の終点が 求められなかった。また，測定試料中に $240 \mathrm{~nm}$ 近傍の 吸収のないこと，測定がより簡便であるこ となど, 吸光度測定法の方がより適していると考 えられた。

e） カタラーゼ（過酸化水素分解）活性の 検出 法

GAM 寒天平板発生集落，および菌体破砕抽出 液中のカタラーゼ活性は Cowan の方法“浞い， 過酸化水素の分解による 発泡より検出した。

f）細菌の産生する過酸化水素の検出法

GAM 寒天平板発生集落を大気中に放置し，そ の集落を硫化水素によって黒変させた酢酸鉛紙に 接触させ, 退色の有無より検出した ${ }^{33)}$ 。

5）タンパク質量の 測定法

タンパク質量は Lowry の方法 ${ }^{34)}$ に従い, Folin-Ciocalteu 試薬を用いて測定した。

\section{結果と考察}

\section{全 NADH 酸化活性}

全 NADH 酸化の活性を各菌種について測定比 較した結果を Table 1 に示す。

本実験結果から, 好気性菌の方が嫌気性菌より, 全 NADH 酸化活性が強いことが示唆される。こ の点は，腸管内の obligate anaerobes, 28菌株が 嫌気条件下で示寸全 NADH 酸化活性について Uesugi と Yajima ${ }^{26)}$ が調べた結果と同じ傾向を示 している。

また, 本実験で, 好気振盪培養と静置培養の 2 条件下に全 $\mathrm{NADH}$ 酸化活性を比較した結果は, 全 NADH 酸化活性が酸素により誘導されること を明らかにしている。

$$
\text { スーパーオキサイド・ディスムターゼ（SOD） }
$$

\section{活性}

SOD 生成に対する酸素の 誘導効果について調 べた結果を Table 2 に示す。Obligate aerobes の SOD 活性については, 静置培養での增殖が認め られなかったため, 酸素による 誘導効果を判定す ることができなかった。Facultative anaerobes で ある E. coli $\mathrm{K}$ 12では，酸素による誘導効果に より SOD 活性は1.8倍に, Staph. aureus $209 \mathrm{P}$ では1.5倍に増加した。Aerotolerant anaerobes お

Table 1 NADH oxidation activity in bacteria

\begin{tabular}{lcc}
\hline \multicolumn{1}{c}{ Strain } & \multicolumn{2}{c}{$\begin{array}{c}\text { NAH peroxidase activity } \\
\text { (U/mg of protein) }\end{array}$} \\
\cline { 2 - 3 } & Shaking in air. & Not shaking. \\
\hline Obligate aerobes & 0.2 & \\
M. subflava S-1 & 0.1 & N.G. ${ }^{\text {a) }}$ \\
Ps. aeruginosa S-2 & & N.G. \\
\hline Facultative anaerobes & 0.6 & N.D. ${ }^{\text {b) }}$ \\
E. coli K 12 & & \\
Aerotolerant anaerobes & 113 & N.D. \\
Str. faecalis ATCC 9756 & 26.5 & N.D. \\
Str. mutans Pk 1 & 0.2 & 0.4 \\
Str. faecalis ATCC 19433 & N.D. & 0.1 \\
L. acidophilus ATCC 4356 & N.D. & 0.2 \\
Str. mitior S-8 & &
\end{tabular}

a) No growth is abbreviated as N.G.

b) No detection is abbreviated as N.D. 
Table 2 Superoxide dismutase (SOD) activity in bacteria

\begin{tabular}{|c|c|c|}
\hline \multirow{2}{*}{ Strain } & \multicolumn{2}{|c|}{ SOD activity ( $\mathrm{U} / \mathrm{mg}$ of protein) } \\
\hline & Shaking in air. & Not shaking. \\
\hline \multicolumn{3}{|l|}{ Obligate aerobes } \\
\hline$M$. luteus NCTC $2665^{\mathrm{a})}$ & 0.8 & N.G. $\left.{ }^{b}\right)$ \\
\hline N. subflava $\mathrm{N}-1$ & 1.0 & N.G. \\
\hline N. subflava $\mathrm{S}-1$ & 0.2 & N.G. \\
\hline Ps. aeruginosa S-2 & 0.6 & N.G. \\
\hline \multicolumn{3}{|l|}{ Facultative anaerobes } \\
\hline E. coli $\mathrm{K} 12$ & 10.3 & 5.7 \\
\hline Staph. aureus $209 \mathrm{P}$ & 5.7 & 3.8 \\
\hline \multicolumn{3}{|l|}{ Aerotolerant anaerobes } \\
\hline Str. salivarius TS-S & 14.9 & $N . . D^{c)}$ \\
\hline Str. salivarius HTS-1 & 7.7 & N.D. \\
\hline Str. salivarius EFS-2 & 9.6 & N.D. \\
\hline Str. salivarius MNS & 18.9 & 3.9 \\
\hline Str. pyogenes IID 689 & 1.7 & 1.0 \\
\hline Str. sanguis S-9 & 0.7 & 0.6 \\
\hline Str. mutans 1089 & 0.5 & 1.1 \\
\hline Str. faecalis 19433 & 2.3 & 11.2 \\
\hline Str. salivarius S-6 & N.D. & 0.7 \\
\hline L. acidophilus ATCC 4356 & N.D. & 0.2 \\
\hline Str. mitior S-8 & N.D. & 0.2 \\
\hline \multicolumn{3}{|l|}{ Obligate anaerobes } \\
\hline$V$. alcalescens ATCC 17748 & 24.3 & 0.2 \\
\hline Prop. acnes ATCC 11827 & N.G. & 1.6 \\
\hline$F$. nucleatum IID 891 & N.G. & N.D. \\
\hline
\end{tabular}

a) Culture medium for this strain is an enriched medium, M. broth.

b) No growth is abbreviated as N.G..

c) No detection is abbreviated as N.D..

よび obligate anaerobes のいくつかの株もまた， SOD 活性を示した。

また, aerotolerant anaerobes については，酸 素による SOD 生成能の誘導効果に関して 3 群に 分けられることが示された。すなわち，i）誘導 効果の著しい群, ii）誘導効果の認められない群, iii）酸素の存在により SOD 生成の抑制される群 の 3 群である。このことは極めて興味媣い事実と 思われる。

また，V. alcalescens ATCC 177481は, 従来 obligate anaerobes であるとされてきた ${ }^{35-37)} に も$ かかわらず，酸素の存在により SOD が多量に誘 導され, 好気振盪培養した時の 比活性が静置培養
した時の 122 倍にも達していた。このことは, 熱 海, 上羽らの 報告 ${ }^{38)}$ とも一致し, 極めて興味深い 事実と思われる。

$$
\begin{aligned}
& \text { スーパーオキサイド・ディスムターゼ（SOD） } \\
& \text { のアイソザイム }
\end{aligned}
$$

さらに, 酸素に対する 抵抗性は, 細菌が保有す る酸化還元酵素の 種類だけではなく，個々の酸化 還元酵素のアイソザイムの構成にも大きく依存す ると考えられる。そのため，酸素の影響が最も微 妙な aerotolerant anaerobes について SOD の アイソザイムの 検出を行った。

Table 3 に示すごとく, Streptococcus の SOD は，1 種類のみであったが, Str. mutans $\mathrm{Pk} 1$ 
Table 3 Localization of superoxide dismutase on polyacrylamide gel

\begin{tabular}{|c|c|c|c|c|c|c|}
\hline \multirow{2}{*}{ Strain } & \multirow{2}{*}{$\begin{array}{l}\text { Sp. act of SOD } \\
\text { (U/mg of protein) }\end{array}$} & \multicolumn{5}{|c|}{$\mathrm{R}_{\mathrm{m}}$} \\
\hline & & $0-0.19$ & $\begin{array}{c}0.20 \\
-0.39 \\
\end{array}$ & $\begin{array}{l}0.40 \\
-0.59 \\
\end{array}$ & $\begin{array}{c}0.60 \\
-0.79 \\
\end{array}$ & $\begin{array}{l}0.80 \\
-1.0 \\
\end{array}$ \\
\hline \multicolumn{7}{|l|}{ Obligate aerobes } \\
\hline N. subflava $\mathrm{N}-1^{* \mathrm{a})}$ & 1.3 & & & & 0.71 & \\
\hline \multicolumn{7}{|l|}{ Facultative anaerobes } \\
\hline E. coli $\mathrm{K} 12^{*}$ & 6.5 & 0.07 & 0.38 & 0.51 & 0.72 & \\
\hline Staph. aureus $209 \mathrm{P}^{*}$ & 22.7 & & & & & 0.97 \\
\hline \multicolumn{7}{|l|}{ Aerotolerant anaerobes } \\
\hline Str. mutans $\mathrm{Pk} 1$ & 66.8 & & & & & $0.93,0.9$ \\
\hline Str.mutans Ingbritt & 2.8 & & & & & 0.90 \\
\hline Str. mutans 1089 & 1.4 & & & & & 0.95 \\
\hline Str. mutans B 13 & 5.5 & & & & & 0.86 \\
\hline Str. mutans MT 703 & 6.1 & & & & & 0.88 \\
\hline Str. mutans OMZ 175 & 6.1 & & & & & 0.88 \\
\hline Str. faecalis ATCC 19433* & 1.2 & & & & & 0.92 \\
\hline \multicolumn{7}{|l|}{ Obligate anaerobes } \\
\hline V. alcalescens ATCC 17748 & 0.2 & & & & 0.61 & 0.91 \\
\hline Prop. acnes ATCC 11827 & 1.6 & & & & 0.65 & \\
\hline
\end{tabular}

a) Air shaking culture is described as *.

Table 4 Catalase activity in bacteria

\begin{tabular}{|c|c|c|}
\hline \multirow{2}{*}{ Strain } & \multicolumn{2}{|c|}{ Catalase activity (U/mg of protein) } \\
\hline & Shaking in air. & Not shaking. \\
\hline \multicolumn{3}{|l|}{ Obligate aerobes } \\
\hline M. luteus NCTC $2665^{\mathfrak{a})}$ & 112 & N.G. ${ }^{\text {b) }}$ \\
\hline N. subflava S-1 & 6.0 & N.G. \\
\hline Ps. aeruginosa $\mathrm{S}-2$ & 405 & N.G. \\
\hline \multicolumn{3}{|l|}{ Faculatative anaerobes } \\
\hline E. coli $\mathrm{K} 12$ & 0.2 & N.D.b) \\
\hline Staph. aureus $209 \mathrm{P}$ & 681 & N.D. \\
\hline \multicolumn{3}{|l|}{ Obligate anaerodes } \\
\hline V. alacalescens ATCC 17748 & 38.1 & 102 \\
\hline Prop. acnes ATCC 11827 & N.G. & 10.0 \\
\hline
\end{tabular}

a) Culture medium for this strain is an enriched medium, M. broth.

b) No growth is abbreviated as N.G..

c) No detection is abbreviated as N.D..

は例外的に 2 本のバンドを有していることが認め られた。既に報告した microaerophilic bacteria である Campylobacter 属の $\mathrm{SOD}^{391}$ とは，大き く異ったアイソザイム構成を持つ点が注目され る。

\section{カタラーゼ活性}

カタラーゼ活性は, 本実験に使用した obligate aerobes, facultative anaerobes の総ての細菌に存 在することが認められた (Table 4)。 facultative anaerobes である E. coli K 12,

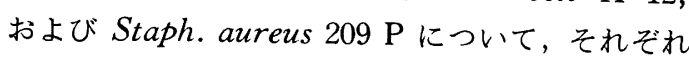
の静置培養後に得られた洗涤菌体破砕抽出液は, 共に定性的な検出によって発泡の存在が認められ たが，定量法によっては検出されなかった。 $E$. 
coli K 12の好気振盪培養後の洗滌菌体の比活性は $0.2 \mathrm{U} / \mathrm{mg}$ of protein であった。一方, Staph. aureus $209 \mathrm{P}$ の好気振盪培養後の洗滌菌体では, 比活性 $680 \mathrm{U} / \mathrm{mg}$ of protein の值を示す菌体破 砕抽出液が得られた。

酸素によるカタラーゼ活性の誘導効果は, facultative anaerobes において著明であった。

\section{細菌による過酸化水素の発生}

主に aerotolerant anaerobes について, 過酸化 水素生成を調べた。その結果, Str. pyogenes IID 689, L. acidophilus ATCC 4356に生成が認めら れたのに対し, Str. faecalis ATCC 19433, Str. mutans BHT, Str. mutans 1089には生成が認め られなかった。

これらの実験結果から, 以下の議論が可能であ る。すなわち, 従来の説によると, obligate anaerobes および facultative anaerobes では, 酸素 存在下で 細菌が増殖した場合, NADH, FAD な どの作用により生体に有害なスーパーオキサイ ド・アニオン $\left(\mathrm{O}^{-}{ }_{2} \cdot\right)$ が生成する ${ }^{40-42)}$ 。次にスー パーオキサイド・ディスムターゼ（SOD）の作用 により, スーパーオキサイド・アニオンから過酸 化水素 $\left(\mathrm{H}_{2} \mathrm{O}_{2}\right)$ が生成される ${ }^{43,44)}$ 。過酸化水素 は, さらにカタラーゼによって生体に無害な水 $\left(\mathrm{H}_{2} \mathrm{O}\right)$ と酸素 $\left(\mathrm{O}_{2}\right)$ に分解される ${ }^{28,31)}$ 。ゆえに, 細菌が酸素存在下で増殖するためには, 細菌はス 一パーオキサイド・ディスムターゼとカタラーゼ を保有していなければならないと説明されてい る。 ${ }^{281}$

しかし，本実験の結果では，口腔常在細菌の大 多数を占める Streptococcus, Lactobacillus など の aerotolerant anaerobes は，カタラーゼを保有 せず, SOD 活性の低いものもあった。また，こ れらの細菌は，好気的な 条件下で強い $\mathrm{NADH}$ 酸 化活性を示した。この実験結果は, 従来からの Fridovich $^{28)}$ の SOD 説だけでは説明できない。そ のため, aerotolerant anaerobes が好気的な条件 下で増殖できる 理由として, 細菌はカタラーゼの 代りにペルオキシダーゼや $\mathrm{NADH}$ ペルオキシダ 一ゼなどの $\mathrm{NADH}$ 酸化を起こす酵素を生成し， これによって蓄積した過酸化物を 分解しているこ とが考えられた。

\section{結語}

1）スーパーオキサィド・ディスムターゼ （SOD）の生成能は，実験に使用した obligate aerobes, facultative anaerobes の総ての細菌と aerotolerant anaerobes の大部分の細菌において 認められた。Obligate anaerobes では, V. alca lescens ATCC 17748, Prop. acnes ATCC 11827 に SOD 生成能が認められたが， $F$. nucleatum IID 891には認められなかった。

2）酸素による SOD 生成能の誘導は, facultative anaerobes と aerotolerant anaerobes $の-$ 部，および $V$. alcalescens ATCC 17748に認め られた。特に，V. alcalescens においては，好気 培養における比活性は 静置培養の比活性の 122 倍 に達していた。

3） カタラーゼ（過酸化水素分解）活性は, obligate aerobes, facultative anaerobes の総ての 細菌に存在していた。aerotolerant anaerobesに は，カタラーゼ活性は，まったく認められなかっ た。酸素によるカタラーゼ活性生成能の 誘導は, facultative anaerobes において著明に認められ た。

4）スーパーオキサイド・ディスムターゼ (SOD) のアイソザィムは， E. coli K 12，V. alcalescens ATCC 17748, および Campylobacter 属においては，複数に存在していた。 aerotolerant anaerobes である Str. mutans $\mathrm{Pk} 1$ で は， $\mathrm{Rm}$ の近接した 2 種類のアイソザイムが認め られたが，本研究で用いた他の Str. mutans の 菌株では，アイソザイムは認められなかった。

5) aerotolerant anaerobes では，代謝の過 程で過酸化物は，ペルオキシダーゼや NADH ペ ルオキシダーゼにより分解されており, カタラー ゼによらないと推察された。

謝辞：稿を終えるにあたり，御指導と御校閲をいただ きました北海道大学歯学部口腔細菌学講座, 鈴木武教授 に心から感謝致します。

また，御校閲と御鞭捙をいただきました北海道大学歯 学部小児歯科学講座, 及川清教授, 予防歯科学講座, 谷 宏教授に感謝致します。 
抄録: 前報では，酸素に対する増殖性より， 口腔常在細菌を 4 群に区分できること，および各々の客観的 判定法について述べた。今回は, 各群に属する細菌28株を好気振濫培養, および静置培養し, 各細菌より得 られた酸化還元酵素の培地当りの生成量およびタンパク質当りの活性（Sp. act）について比較した。

一般的に obligate aerobes ではカタラーゼ活性は強いが，全 NADH 酸化活性は弱く，スーパーオキサイ ド・ディスムターゼ（SOD）活性は比較的中等度に持っていた。facultative anaerobes では，カタラーゼ活 性は全 NADH 酸化活性と共に中等度であり, SOD 活性は強かった。aerotolerant anaerobes では, カ夕 ラーゼは生成しないが, NADH 酸化活性は最も強かった。 SOD 活性は中等度であった。 obligate anaerobes のうち, カタラーゼを持つ株は, 静置培養でよくカタラーゼを生成した。また，V. alcalescens では，振盪 培養の時, SOD を多量に生成した。

また，これらの細菌12株についてディスク電気泳動を行い，SOD 活性染色をした。Str. mutans Pk1, およびV. alcalescens ATCC 17748 株では，2 種類のアイソザイムが認められた。これらの結果から， aerotolerant anaerobes が好気的な条件でも増殖できる理由として，カタラーゼの代りにペルオキシダーゼ や NADH ペルオキシダーゼを多量に生成し，これによって蓄積した過酸化物を分解していることが考えら れた。

\section{文献}

1) Aranki, A., Syed, S. A., Kenney, E. B. and Freter, R.: Isolation of anaerobic bacteria from human gingiva and mouse cecum by means of a simplified glove box procedure. Appl. Microbiol. 17 :568-576, 1969.

2) Burnett, G. W., Scherp, H. W. and Schuster, G. S.: Oral microbiology and infectious disease., 4 th ed., pp. 76-80, Williams \& Wilkins Company, Tronto, New York, 1976.

3）菊池裕子：口腔常在細菌の增殖性と酸化還元酵 素について. I. 各種酸素檂度下における口腔常 在細菌の増殖性. 歯基礎誌 27:1169-1177, 1985.

4) Cowan, S. T.: Manual for the identification of medical bacteria, 2nd ed., Cambridge at the University Press, Cambridge, 1974.

5) Washburn, M. R., White, J. C. and Niven, C. F. Jr.: Streptococcus S. B. E. Immunological characteristics. J. Bacteriol. $51: 723-729,1946$.

6) Krasse, B.: Human Streptococci and experimental caries in hamsters. Arch. Oral Biol. $11: 429,1966$.

7）深津利雄, 日比栄子, 戸松功克, 伊豆 惊, 伊 豆 康, 武井 盈: Str. mutans の検出, 一般 性状, 核酸組成および八ムスター感染実験. 愛 院大歯誌 9: 24-31, 1971.

8) Hamada, S. and Slade, H. D. : Purification and immunochemical characterization of type e polysaccharide antigen of Streptococcus mutans. Infect. Immun. $14: 68-76,1976$.

9) Gibbons, R. J., Berman, K. S., Koetherner, P. and Kapsimalis, B. : Dental caries and alveolar bone loss in gnotobiolotic rate infected with capsuleforming Streptococci of human origin. Arch. Oral Biol. 11 : 549, 1966.

10) Guggenhiem, B.: Streptococci of dental plaques. Caries Res. 2:247, 1968.

11) Edwardson, S.: Characteristics of caries inducing human Streptococci resembling Streptococcus mutans. Arch. Oral Biol. $13: 637,1968$.

12) Whittenbury, R.: The differentiation of Streptococcus faecalis and $S$. faecium. J. Gen. Microbiol. $38: 279,1965$.

13) Sherman, J. M. and Niven, C. F. Jr. and Smiley, K. L.: Streptococcus salivarius and other non-hemolytic Streptococci of the human throat. J. Bacteriol. $45: 249-263$, 1943.

14) Okamoto, H., Shoin, S. and Minami, M.: Experimental anti-cancer studies part XXX. Factors influencing the Streptolysin S form. ing ability of Streptococci having anti-cancer activity. Japanese J. Exp. Med. 36: 161174, 1966.

15) Hansen, P. A. and Mocquot, G.: Lactobacillus acidophilus(Moro) comb. Nov. Int. J. Syst. Bacteriol. 20 : 325-327, 1970.

16) Rogasa, M.: The genus Veillonella IV. Serological groupings, and genus and species emendations. J. Bacteriol. 90 : 704-709, 1965.

17) Moore, W. E. C. and Cato, E. P.: Validity of Propionibacterium acnes(gilchrist) doug. las and gunter comb. nov. J. Bacteriol. 85 : 870-874, 1963.

18) Knorri, M.: Über die fusispirillare symbiose, die Gattung Fusobacterium (K. B. Lehman) and Spirillum sputigenum, $\mathrm{Zbl}$. Bakt. I. Orig. 87 : 536-545, 1922. 
19) Lim, P. G. and Mateles, R. I. : Tryptophan and indole-excreting prototrophic mutant of Escherichia coli. J. Bacteriol. $87: 1051$ 1055, 1964.

20) Ginsberg, D. M. and Jagger, J. : Possible errors arising from the use of fritted-glass filters for bubbling of cell suspensions, especially in irradiation experiments. J. Bacteriol. 83 : 1361-1362, 1962.

21) Kladius, L. E., Zing, H. K. and Sutton, C. R.: Decarboxylation of neutral amino acids in Proteus vulgaris. J. Gen. Microbiol. $17: 602-119,1957$.

22) Kauffman, F. and Edwards, P. R. : Classification and nomenclature of Enterobacteria. ceae. Int. Bull. Bact. Nomencl. Taxon 2 : $2,1952$.

23) Fleming, A.: On a remarkable bacteriolytic element found in tissues and secretions. Proc. R. Soc. Lond [Biol] 93 : 306, 1922.

24) Locur, M., Pacova, Z. and Martinec, T. : Taxonomic status of Micrococcus luteus (Schroeter 1872)Cohn 1872, and designation of the neotype strain. Int. J. Syst. Bacteriol 22 : 218-227, 1972.

25) Dolin, M. I.: The Streptococcus faecalis oxidases for reduced diphosphopyridine nucleotide. III. Isolation and properties of a fla. vin peroxide for reduced diphosphopyridine nucleotide. J. Biol. Chem. 225 : 557-567, 1957.

26) Uesugi, I. and Yajima, M.: Oxygen and strictly anaerobic intestinal bacteria. II. Oxygen metabolism in strictly anaerobic bacteria. Zeitschrift für Allgemeine Mikrobiologie 18 : 593-601, 1978.

27) Mizushima, S. and Kitahara, K. : Purification and properties of DPNH peroxidase in Lactobacillus casei. J. Gen. Appl. Microbiol. $8: 56-62,1962$.

28) McCord, J. M., Keel, B. B. Jr. and Fridovich, I. : An enzyme-based thory of obligate anaerobiosis: The physiological function of superoxide dismutase. Proc. Nat. Acad. Sci. USA. 68 : 1024-1027, 1971.

29) Davis, B. J. and Ornstein, L.: Disc electrophoresis. I. Background and theory. Ann. NY. Acad. Sci. 121 : 321-424, 1964.

30) Beauchamp, C. and Fridovich, I. : Superoxide dismutase; Improoved assays and an assay applicable to acrylamide gels. Anal. Chem. 44 : 276-287, 1971.
31) von Euler, H. and Josephson, K. : Activity of horse-liver catalase. Ann. 452 : 158-165, 1927.

32) Beers, R. F. and Sizer, I. W. : A spectrophotometric method for measuring breakdown of hydrogen peroxide by catalase. J. Biol. Chem. 220 : 133-140, 1951.

33) A-Whatman International Company : $\mathrm{pH}$ indicator and test papers., Whatman publication 8251P: Whatman Ltd., Spring-field Mill, Maidstone, Kent, ME14 2LE England, 1985.

34) Lowry, O. H., Rosenbrough, N. J., Farr, A. L. and Randal, R. J.: Protein measurement with the Folin phenol reagent. J. Biol. Chem. 193 : 265-275, 1951.

35) Buchanan, R. E. and Gibbons, N. E. : Bergey's Manual of Determinating Bacteriology. pp. 490-592, The Williams \& Wilkins Co. Baltimore, 1974.

36）小酒井望，鈴木祥一郎編：嫌気性菌と嫌気性菌 症, pp. 93-94, 医学書院, 1968.

37) Cowan, S. T. : Cowan and Steel's Manual for the Identification of Medical Bacteria, pp. 105-113, Cambridge University Press, 1974.

38）熱海智子, 上羽隆夫 : 嫌気性菌 Veillonella alcalescens の増殖における酸素の影響. 歯基礎 誌 26(補再) : 387, 1984.

39) Kikuchi, H. E. and Suzuki, T.: An electrophretic analysis of superoxide dismutase in Campylobacter spp. J. Gen. Microbiol. 130 : 2791-2796, 1984.

40) Gottshalk, G. : Bacterial Metabolism, Springer-Verlag, Berlin, Heidelberg, 1979.

41) Britton, L., Malinowski, D.P. and Fridovich, I. : Superoxide dismutase oxygen metabolism in Streptococcus faecalis and comparisons with other organisms. J. Bacteriol. $134: 229-$ 236, 1978.

42) Carlsson, J., Iwami, Y. and Yamada, T. : Hydrogen peroxide excretion by oral Streptococci and effect of lactoperoxidase-thiocyanate-hydrogen-peroxide. Infect. Immun. 40 : 70-80, 1983.

43) Brock, T. D. : Biology of Micro-organisms, 2nd ed., 313-318, Prentice Hall Inc., Englewood Cliffs, Newjersey, 1974.

44）浅田浩二：植物䤉素・蛋白質研究法, スーパー オキサイド・ディスムターゼ.（蛋白・核酸・ 酵素編), pp. 373-378, 共立出版, 東京, 1976. 